\title{
Author Correction: Targeted gadofullerene for sensitive magnetic resonance imaging and risk- stratification of breast cancer
}

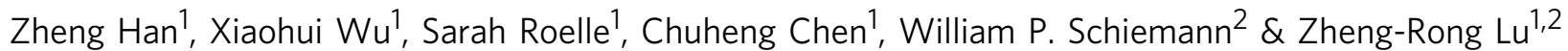

Correction to: Nature Communications https://doi.org/10.1038/s41467-017-00741-y, Article published online 25 September 2017

In the original version of this Article, the penultimate sentence of the Abstract incorrectly read 'The dose of the contrast agent for effective molecular MRI is only slightly lower than that of ZD2-Cy5.5 $\left(0.5 \mu \mathrm{mol} \mathrm{kg}{ }^{-1}\right)$ in fluorescence imaging.' The correct version states 'higher' in place of 'lower'. This error has been corrected in both the PDF and HTML versions of the Article.

Published online: 08 January 2018

\begin{abstract}
(c) (i) Open Access This article is licensed under a Creative Commons Attribution 4.0 International License, which permits use, sharing, adaptation, distribution and reproduction in any medium or format, as long as you give appropriate credit to the original author(s) and the source, provide a link to the Creative Commons license, and indicate if changes were made. The images or other third party material in this article are included in the article's Creative Commons license, unless indicated otherwise in a credit line to the material. If material is not included in the article's Creative Commons license and your intended use is not permitted by statutory regulation or exceeds the permitted use, you will need to obtain permission directly from the copyright holder. To view a copy of this license, visit http://creativecommons.org/licenses/by/4.0/.
\end{abstract}

(c) The Author(s) 2018

\footnotetext{
${ }^{1}$ Case Center for Biomolecular Engineering, Department of Biomedical Engineering, Case Western Reserve University, 10900 Euclid Avenue, Cleveland, OH 44106, USA. ${ }^{2}$ Case Comprehensive Cancer Center, Case Western Reserve University, Cleveland, OH 44106, USA. Zheng Han and Xiaohui Wu contributed equally to this work. Correspondence and requests for materials should be addressed to Z.-R.L. (email: zxl125@case.edu)
} 